https://helda.helsinki.fi

\title{
Religion as a Liturgical Continuum
}

\section{Gillin, Joel T F}

2019-12

Gillin , J T F 2019 , ' Religion as a Liturgical Continuum ', Neue Zeitschrift für systematische pÿTheologie und Religionsphilosophie. , vol. 61 , no. 4 , pp. 549569 . https://doi.org/10.1515/nzsth-2019-0028

http://hdl.handle.net/10138/322066

https://doi.org/10.1515/nzsth-2019-0028

publishedVersion

Downloaded from Helda, University of Helsinki institutional repository.

This is an electronic reprint of the original article.

This reprint may differ from the original in pagination and typographic detail.

Please cite the original version. 


\title{
Joel Gillin*
}

\section{Religion as a liturgical continuum}

\author{
https://doi.org/10.1515/nzsth-2019-0028
}

Summary: This article considers the utility of a liturgical lens for locating and analyzing religion in the public sphere. Dominant paradigms in the study of religion tend to either dissolve the religious/secular distinction or base it on overly cognitive content. Drawing on the work of James K. A. Smith, the article outlines an approach which instead locates religion in embodied practices that shape human desire. I suggest the religious/secular binary is better conceptualized as a continuum in which liturgical intensity is the primary criterion of religiosity. A liturgical continuum better articulates the contested nature of public space and the religious aspects of political life.

Keywords: Liturgy, James K. A. Smith, Religion in the Public Sphere, Secular, Desire

Zusammenfassung: Dieser Artikel befasst sich mit der Nützlichkeit einer liturgischen Linse zur Lokalisierung und Analyse von Religion in der Öffentlichkeit. Vorherschende Paradigmen in der Religionswissenschaft neigen entweder dazu, die Unterscheidung zwischen religiös und säkular aufzulösen oder sie auf übermäßig kognitive Inhalte zu stützen. In Anlehnung an James K. A. Smith beschreibt der Artikel einen Ansatz, der Religion stattdessen in verkörperten Praktiken findet, die das menschliche Verlangen formen. Ich schlage vor, dass das religiöse / säkulare Binärsystem besser als ein Kontinuum aufgefasst werden sollte, in dem die liturgische Intensität das Hauptkriterium der Religiosität ist. Ein liturgisches Kontinuum bringt die umstrittene Natur des öffentlichen Raums und die religiösen Aspekte des politischen Lebens besser zum Ausdruck.

Schlüsselwörter: Liturgie, James K. A. Smith, Religion in der Öffentlichkeit, säkular, Verlangen

The simultaneous phenomena of secularization and increasing religious and cultural pluralism in many Western countries ensure the continued debate regarding religion's role in the public sphere. A perennial challenge for scholars investigating

*Corresponding author: Joel Gillin, Department of Systematic Theology, University of Helsinki, PL 4, Vuorikatu 3, 00014 Helsinki, E-Mail: joel.gillin@helsinki.fi 
and theorizing the relationship between religion and politics is articulating a useful definition of religion on which to base those discussions. While the religious/secular binary birthed in the modern era has been challenged in recent years by the public resurgence of religion, defining religion-or choosing not to-is still fraught with difficulties. ${ }^{1}$ The field of religious studies' lack of consensus regarding the definition of religion has led one scholar to state that the inability to define religion has become "almost an article of methodological dogma" in the field. ${ }^{2}$

This article considers the usefulness of a liturgical approach to religion for informing discussions about its role in public spaces. I will first give an overview of the definitional problem of religion and outline the main difficulties the dominant strategies face in informing such discussions. ${ }^{3}$ I will then assess a proposal by Kevin Schilbrack for understanding religion, arguing that his religious/nonreligious distinction is too cognitive to adequately deal with the complex space inhabited by religion and politics. I will then draw on the work of philosopher James K. A. Smith and others to outline how a liturgical lens would shed light on these discussions. By locating religion in ultimate desires shaped by formative liturgies, I will suggest that the religious/secular binary is better conceptualized as a liturgical continuum. I argue that this strategy avoids the problematic aspects of previous definitions and enables better analysis of contested spaces in pluralistic societies. In the conclusion, I discuss how religion as a liturgical continuum would shed light on various aspects of the study of religion, including secularization, religious incongruence, and the inescapability of religion's presence in public spaces.

\section{Debating the utility of "religion"}

How does one distinguish between religious groups, arguments, and behavior from those of secular or nonreligious groups? In a widely cited article on defining religion, Jonathan $\mathrm{Z}$. Smith describes the importance of the task when he writes that religion is a "second-order, generic concept that plays the same role in estab-

1 José Casanova, Public Religions in the Modern World (Chicago: University of Chicago Press, 1994); Peter Berger, ed., The Desecularization of the World: Resurgent Religion and World Politics (Grand Rapids: Eerdmans, 1999), 2.

2 Brian C. Wilson, "From the Lexical to the Polythetic: A Brief History of the Definition of Religion," in What is Religion? Origins, Definitions, and Explanations, eds. Thomas A. Idinopulos and Brian C. WiLson (Leiden: Brill, 1998).

3 I will use the terms "definition," "approach,” "strategies," and other similar terms roughly interchangeably. 
lishing a disciplinary horizon that a concept such as 'language' plays in linguistics or 'culture' plays in anthropology. There can be no disciplined study of religion without such a horizon." In this section of the article, I will outline the shortcomings of the two dominant approaches to defining religion: substantive and functionalist. I will then consider a recent proposal by philosopher Kevin Schilbrack to overcome these shortcomings and explain why I think it ultimately does not succeed.

\section{Substantivism}

The substantivist approach to defining religion is common in contemporary popular-level discussions, but it is also prevalent in academic literature as well. Substantivist (or "real") definitions of religion seek to identify some essential content found in all religions; this content is generally belief in "transcendence," such as gods or the supernatural. A classic instance of this is the anthropologist Edward Tylor's early definition in Primitive Culture (1871) which located religion in the beliefs and practices related to supernatural entities. ${ }^{5}$ Substantivist definitions such as these face two main problems: The first is that to include everything scholars of religion typically want to study, like Buddhism or Confucianism, "transcendence," "supernatural," or "powers” must necessarily be vague. Vague notions of transcendence, however, make it difficult or impossible to exclude ideologies and traditions such as nationalism or Marxism, which are often treated as distinct from religion. In addition, defining transcendence may prove at least as difficult a task. ${ }^{6}$ If that is the case, then placing a set of beliefs and practices in the category of religion becomes arbitrary due to a lack of coherent criteria, rendering the label "religious" of questionable value.

The other main, and perhaps more serious, challenge facing substantivist definitions is the charge of essentialism. In recent decades, many scholars have declared the category of religion wholly artificial and the search for a stable, univer-

4 Jonathan Z. Sмгтн, "Religion, Religions, Religious," in Critical Terms for Religious Studies, ed. Mark C. TAYLoR (Chicago: University of Chicago Press, 1998), 281-282. Smith has also said that "religion" is a constructed category without "no independent existence apart from the academy" (Jonathan Z. Sмітн, Imagining Religion: From Babylon to Jonestown [Chicago: University of Chicago Press, 1982], xi). I will address this claim below.

5 Edward Burnett Tylor, Religion in Primitive Culture (Gloucester: Peter Smith, 1970).

6 William T. CAvanaugh, The Myth of Religious Violence: Secular Ideology and the Roots of Modern Conflict (New York: Oxford University Press, 2009), 105. 
sal element present in all religions as futile. ${ }^{7}$ The critique often positions the religious as a construct necessarily connected with and opposed to the concept of the secular. Drawing on scholars like Michel Foucault and Jacques Derrida, this "genealogical" critique claims the religion is a specifically modern, Western category rooted in Enlightenment thought. On this account, the religious/secular distinction itself is a culturally-situated, contingent construct which seeks to mask its own particularity and universalize it as if it was simply the way things are. As Talal Asad, a prominent proponent of this view, has written, "there can be no universal definition of religion, not only because its constitutional elements and relationships are historically specific, but because that definition is itself the historical product of discursive processes."

\section{Functionalism}

Seeking to avoid the pitfalls of substantivist approaches and enable cross-cultural study of religion, other scholars have pursued a functionalist strategy which purports to describe what it does, i.e. how it functions, rather than define it based on the substantive content. This line follows the tradition of Émile Durkheim who held that religion maintains social cohesion through "a unified system of beliefs and practices relative to sacred things, that is to say, things set apart and surrounded by prohibitions." $\mathrm{A}$ key weakness of this approach is that the content of the sacred, as with vague notions of "transcendence" in substantive definitions, can be filled by anything. For a functionalist, any set of practices or ideology can be religious simply based on its function. That is why a functionalist can coherently argue that economic systems function as a religion, or at least have this potential. ${ }^{10}$ While this functionalist strategy may have certain analytic uses in the study of groups and societies, depending on one's purposes, it is unable to distin-

7 See William C. Sмгтн, The Meaning and End of Religion (New York: Macmillan, 1962); Daniel Dubuisson, The Western Construction of Religion, trans. William Sayers (Baltimore: Johns Hopkins University Press, 2003); William Arnal and Russell McCutcheon, The Sacred Is the Profane: The Political Nature of 'Religion' (Oxford: Oxford University Press, 2012); Christopher R. CotTeR and David G. RoBertson, After World Religions: Reconstructing Religious Studies (Basingstoke: Routledge, 2016); among many others.

8 Talal AsAd, Genealogies of Religion: Discipline and Reasons of Power in Christianity and Islam. (Baltimore: Johns Hopkins University Press, 1993), 9.

9 Émile Durkheim, The Elementary Forms of Religious Life, trans. Carol Cosman (Oxford: Oxford University Press, 2001), 46.

10 David R. Loy, “The Religion of the Market," Journal of the American Academy of Religion 65 (1997), 275-290. 
guish between religious phenomena from political or any other kind of social phenomena. This is a clear problem for those seeking to maintain the religious/ secular distinction and thus differentiate religion from politics both institutionally and in the realm of public discourse. As William Cavanaugh says, "If nearly every ideological system or set of practices can be a religion, then calling something religious does not help to distinguish it from anything else."11

Functionalist definitions are often not really definitions but "more accurately described as assertions about the origins or common consequences of religion." 12 That is, they do not provide necessary and sufficient conditions for what constitutes religion. That does not mean they cannot be useful for certain purposes, only that they are not equipped to distinguish between religious phenomena and nonreligious phenomena. More problematic for those concerned to avoid the pitfalls of substantivism is that the functionalist approach presupposes a substantivist understanding of religion and commits the same essentialist fallacy. As has been noted by other scholars, though this approach focuses on the function of religion rather than what it is, in the end the function simply is the essential characteristic. Schaffalitzky de Muckadell has pointed out that if religion functions as an opiate of the masses, then "the essence of religion is that it functions as an opiate of the masses."13 Functionalist definitions then are really just a subset of real, essentialist definitions and open to the same critiques. ${ }^{14}$

Given the difficulties of these definitions, the temptation to abandon the term "religion," and thus the religious/secular distinction, is great. This would lead one to abandon the notion of "religious" communities, practices, and beliefs as distinct from those merely political, social or otherwise secular or nonreligious. But acknowledging the difficulty of these strategies does not necessitate that one declare the term "religion" to be without use, nor need one conclude there are no real social phenomena in the world corresponding to the term. For one thing, to drop the term entirely seems undesirable because, despite various attempts, ${ }^{15}$

11 Cavanaugh (see above, n. 6), 106.

12 Steve BRuce, "Defining Religion: A Practical Response," International Review of Sociology 21 (2011), 107-120, here: 111.

13 Caroline Schaffalitzky de Muckadell, "On Essentialism and Real Definitions of Religion," Journal of the American Academy of Religion 82 (2014), 495-520, here: 497-498; See also Melford E. SpIro, "Religion: Problems of Definition and Explanation," in Anthropological Approaches to the Study of Religion, ed. Michael Banton (London: Tavistock, 1966), 89.

14 Other attempts to avoid essentialism, as with mere stipulative definitions and prototype approaches, also have significant drawbacks, though space does not permit discussion. See ScHAFFALitZKy de MucKadell (see above, n. 13), 499-502.

15 E.g., Dubuisson (see above, $\mathrm{n}$.7). Dubuisson argues here for the term "cosmographic formation." 
there are no obvious alternatives without similar difficulties. The term is also so widespread in academic and popular usage that a wholesale rejection of the term seems highly unrealistic. Instead, it is preferable to rework the term towards a definition that sheds problematic aspects while incorporating more analytically useful categories. Along with others, I think the best way to judge a definition of religion is by its usefulness for its stated purposes. ${ }^{16}$ To consider a recent proposal with a strong case for why scholars should continue talking about "religion" and making the religious/secular distinction, I will now turn to the recent work of Kevin Schilbrack.

\section{Kevin Schilbrack's hybrid approach}

Schilbrack approaches the subject of religion and its definition as a philosopher. ${ }^{17}$ Schilbrack rejects what he calls the "naive" realism (what I will call "natural" realism) that believes religion has some transcultural, objective character that is captured in typical substantive definitions. He takes seriously what he sees as a three-fold critique of "religion": that it is social construction which essentializes different ways of life and imports ideological baggage from its association with Western and imperialist projects. Yet he rejects the anti-realist conclusion of religion's nonexistence which many consider as the consequence of these critiques. ${ }^{18}$ To say religion, as such, does not exist, is to misunderstand the ontology of social realities. Drawing on the work on John Searle, ${ }^{19}$ Schilbrack says that the social practices and institutions of religion, though facts which are constructed and contingent, are nonetheless facts. The term describes something out there in the world. The same is true of the ontology of other social phenomena, such as colonialism or economics. He sights the apt summary of Talal Asad in reference to the

16 This is argued by e.g. Peter L. BERgER, The Sacred Canopy: Elements of a Sociological Theory of Religion (New York: Doubleday, 1967) and more recently by Brent NoNGBRI, Before Religion: A History of a Modern Concept (New Haven: Yale University Press, 2013).

17 Kevin Schilbrack, Philosophy and the Study of Religions: A Manifesto (Surrey: Wiley-Blackwell, 2014). I will also be citing articles on which this monograph is based.

18 Kevin Schilbrack, “Religions: Are there any?” Journal of the American Academy of Religion 78 (2010), 1112-1138, here: 1112.

19 John R. Searle, The Construction of Social Reality (New York: The Free Press, 1995). The main distinction here is that socially dependent facts are ontologically subjective, i.e. would cease to exist without humans. But they are still epistemologically objective regardless of one's personal opinions about them (e.g. that a particular person is president or that private property exists). See Schilbrack (see above, n. 18), 1118-1119. 
nation: "This construct [the nation] is no less real for being ideological." ${ }^{20}$ Schilbrack thus takes a critical realist stance toward religion: he acknowledges the social reality of phenomena and the usefulness of interpreting some of it as "religion," but he adds the reflexivity gained from the constructionist critique which admits that no interpretation will be free from the contingencies of the scholars' own language and culture. The concept, he says, is best understood as a heuristic tool which is neither true nor false but is rather to be judged by how useful it is for the purposes stated by those who employ it.

The strategy for defining religion that Schilbrack outlines combines functionalist and substantivist approaches. Because of the difficulties noted above, Schilbrack claims that a definition of religion which provides analytic value and enables the empirical study of religion will need to have both pragmatic and ontological elements. That is, religion cannot simply be social practices which provide meaning and unite a community of people, nor can it simply be belief in some supernatural order or god or Platonic ideals with no correlating practices. Religion is instead found in the space where these two elements overlap; pragmatically, religion consists of "normative social practices that promise to solve problems for people"; ${ }^{21}$ ontologically, religion makes claims about reality, even if only implicitly so in the practices. ${ }^{22}$

The crux of Schilbrack's strategy for defining religion, and thus for distinguishing between religion and nonreligious beliefs and practices, is found in the nature of the ontological reality claimed. He agrees that the dualism implied in the focus on the supernatural and transcendent has been deeply problematic for the study of religion, arguing that the "study of religion needs to be rematerialized. Assuming dualism is not the way to ground a more inclusive substantive definition." ${ }^{23}$ Instead, the distinction is between what he calls the nonempirical and the superempirical, the latter a subset of the former. Both religious and nonreligious communities make claims about reality which are not empirically verifiable: values and norms such as goodness, honor, patriotism, and so on. The difference is the grounds: nonempirical claims which are not superempirical are purely contingent, wholly dependent on "either the particular social practices of human history or by practical reason as such." 24 Examples provided include devotion to the imagined community of the nation, the invisible hand of the market,

20 Asad (see above, n. 8), 194.

21 Kevin Schilbrack, “What Isn’t Religion?,” The Journal of Religion 93 (2013): 291318, here: 300.

22 Ibid., 304.

23 Ibid., 312. For more on the material turn, see Manuel A. VASQUEz, More than Belief: A Materialist Theory of Religion (Oxford: Oxford University Press, 2011).

24 Schilbrack (see above, n. 21), 313. 
and the Marxist proletariat, provided that these values are viewed by the practitioners solely as the product of human activities. Religious claims are instead authorized by superempirical realities which, while also not being empirically verifiable, are not contingent on humans but instead on some metaphysical character of reality itself which exists outside of the contingency of human societies.

Schilbrack's strategy has several strengths for those interrogating the category of religion vis-a-vis politics and is among the strongest cases to be made for maintaining a religious/secular (or "nonreligious") distinction along the line commonly used. First, he moves past the type of natural realism that is prevalent in much contemporary discussion on the role of religion in politics and violence. ${ }^{25}$ Second, its critical realism means that the scholars of religion, thought chastened by the constructionist critique, are nonetheless studying real social phenomena. This is foundational for those studying the practices and institutions of religions. It affirms the reality of those social phenomena, the study of which is undermined if they are purely the creation of the language we use to describe the world. His account also takes embodiment seriously, a feature which the philosophy of religion, as it has typically been pursued, has lacked.

Despite its strengths, I do not think Schilbrack's strategy ultimately succeeds in overcoming what I think are some untenable assumptions in the common religious/secular distinction. My primary concerns regarding his approach is that the nonempirical/superempirical dichotomy on which is relies contains a lingering tendency to privilege articulated beliefs over pre-reflective, embodied commitments. For Schilbrack's case for differentiating the religious and nonreligious (or, for our purposes, "secular") to hold, the authorization for ontological claims made by communities must be articulated. That is, a community should consciously ground and express its values and norms in either sources that are merely nonempirical or those that are also superempirical. In his example on whether or not war is religious (in this case, the American War on Terror), he states that if one views justice as "not merely the product of the American way of life, American interests, and the U.S. Constitution, but is rather a transcendent aspect of the cosmos, then the war can be read as religious." ${ }^{26}$ One's view of justice, then, must consciously be based the wholly contingent and immanent realities of national interest or constitutional rules, not transcendent notions of justice, for it not to be religious. They also must be expressed as such, as it is difficult to see how else scholars would be able to distinguish one group's approach to justice from that of

25 See Cavanaugh (see above, n. 6) for an extensive discussion of this, particularly Ch. 2.

26 Schilbrack (see above, n. 21), 317. The example is from Ira Chernus, "The War in Iraq and the Academic Study of Religion,” Journal of the American Academy of Religion 4 (2008), 844-873. 
another's. It is not clear, however, that the neo-conservatives cited in this example from Ira Chernus, or anyone engaged in the war itself, would themselves consciously make such ontological distinctions, let alone articulate such a distinction. It is not that explicit articulations do not exist; only that to require that a community specifically be able to say how they authorize their normative claims about the nation or justice before one can categorize them as religious or secular assumes such distinctions are conscious in people's practices. Otherwise, these distinctions would need to be clearly discernible to observers in the practices themselves, and Schilbrack gives no indication that such a possibility exists. The nonempirical/superempirical distinction, and thus the social phenomena categorized as religion, commits a version of the linguistic fallacy: it assumes the primary forms of power in intersubjective relations and explanations of social phenomena is found in linguistic content. ${ }^{27}$ In short, it adopts too cognitive a view of human beings.

This is odd, because Schilbrack very clearly repudiates overly cognitive views of religion and urges philosophers to take embodiment seriously. He notes that the study of religion has been plagued by a Cartesian dualism, and helpfully argued for the need to "bring the study of religion out of the head," advocating "a holistic view of human agent as embodied and social, but nevertheless also with the capacity to imagine, to make judgments about, and to live according to certain beliefs." ${ }^{28}$ While he convincingly argues for retaining belief in the study of religions and (propositional) belief as universal and implicit in all normative practices, he says that beliefs need not be conscious. ${ }^{29}$ Thus it is possible that religions "may seek to cultivate ... certain affections, virtues, and sensibilities, but religious communities usually do not ask their members to believe certain things and they usually do not seek to regulate the members' beliefs." 30 He goes on to say that something can be religion "even if it has not been articulated as a system, does not have a distinct community, makes dances more central to membership than creeds, and is inseparable from the public life of the culture." ${ }^{11}$ With his emphasis on embodiment, pre-reflective practices and no requirement for beliefs to be consciously held, it seems difficult to see how this will allow him to pin the religious/ secular distinction on a community's own articulation of the ontology of the nonor superempirical realities that ground their norms. Another way of stating this

27 Donovan O. Schaefer, Religious Affects: Animality, Evolution, and Power (Durham: Duke University Press, 2015), 7.

28 Schilbrack (see above, n. 17), 70.

29 Ibid., 65.

30 Ibid., 71.

31 Schilbrack (see above, n. 18), 1114. 
concern is this: How many ardent secular nationalists would be conscious that their values are based on entirely contingent social practices? With exalted language in praise of their nation's history and embodied practices which would match or surpass the intensity of a devout religious community, it seems categorization based on the ontology of a source of norms for such a group may mislead scholars seeking to understand the behavior and dynamics of a nationalist movement in the politics and public life of a society.

In short, I think that Schilbrack's strategy for understanding religion, though highly nuanced and reflexive, has not succeeded in giving satisfying criteria for a religious/secular distinction. He has pinpointed the key weakness of the dominant approaches taken by many scholars of religion, but his account is hindered by an insistence on a distinction between the nonempirical and superempirical which seems to obscure the nature of the social practices under investigation. And despite his important work on the relationship between embodiment and belief, he retains the problematic cognitive view of people's orientation towards the source of their normative orders.

In this section, I have argued that unsatisfactory strategies for understanding religion, even the sophisticated approach of Schilbrack, suggest that the religious/secular distinction is on shaky grounds. Rejecting this distinction as found in many modern accounts requires a different conception of religion which will shed light on its role in public spaces, particularly in secular and pluralistic societies. That is the subject of the next section.

\section{Religion through a liturgical lens}

This section is going to outline a liturgical approach to religion which seeks to overcome the anthropological assumptions built into belief-oriented models. Drawing on the work of philosopher James K. A. Smith and his cultural liturgies project, ${ }^{32} \mathrm{I}$ am going to suggest that conceptualizing religion through the lens of a liturgical continuum offers considerable analytic advantages over those examined above in locating religion and its role in public life.

As philosophers seeking to challenge dominant paradigms in the study of religion, Smith and Schilbrack both see the disciplines which study religious phenomena (but perhaps philosophy especially) as overly dependent on the articu-

32 James K. A. Sмгтн, Desiring the Kingdom: Worship, Worldview, and Cultural Formation (Grand Rapids: Baker Academic, 2009).; IDEM., Imagining the Kingdom: How Worship Works (Grand Rapids: Baker Academic, 2013).; IDEm., Awaiting the King: Reforming Public Theology (Grand Rapids: Baker Academic, 2017). 
lated, propositional content which assumes an excessively cognitive picture of human beings. Both draw on postmodern philosophy and the phenomenological tradition to emphasize the importance of embodiment in understanding human being-in-the-world. But while Schilbrack's approach to religion maintains the religious/secular distinction along a fairly traditional line nonempirical/superempirical, Smith's strategy of outlining a more radical philosophical anthropology ends up blurring this line. Emphasizing the primacy of embodiment and pre-conscious modes of being over linguistic content and doctrine, Smith locates religion in human desire shaped by formative rituals and practices, or what he calls liturgies. These liturgies, as we will see, do not neatly fall in either the public/private or religious/secular realm as typically understood.

Along with Schilbrack, because I reject the natural realist view of religion, I do not take it that a liturgical definition is universal or free of the influence of the particular European intellectual traditions from which it draws. Instead, my claim is that this lens is going to be more useful for the purpose of locating and analyzing the "religious" aspects of groups, behaviors, and discourse, particularly in the public spaces of secularizing and diverse. By starting with more holistic anthropological assumptions, a liturgical understanding of religion overcomes an overly cognitive view of social practices and groups to more accurately track the complex, multiple, and often contradictory beliefs and practices of religious and secular communities in modern societies.

Rather than take the core of human be-ing to be articulable thoughts and beliefs, a liturgical anthropology instead seeks a "more holistic, affective, embodied anthropology" in which rituals and material practices gain primacy in explaining human behavior. ${ }^{33}$ This theme is connected with broader discussions related to the conceptual frameworks inherited from Enlightenment rationalism and Cartesian dualism. While these frameworks associated with modernity have been critiqued from a wide range of perspectives, theorists drawing on postmodernism, feminism, phenomenology, and other fields have honed in specifically on the way the focus on language and beliefs has obscured important aspects of human activities and relations. Drawing from these discussions, in addition to theological resources such as Augustine and Neo-calvinist reformational philosophy, Smith's cultural liturgies project seeks to refocus philosophical anthropology from propositional content toward embodied desire. This anthropology suggests that subjectivity is better understood at the "lower," less cognitive level of loves. ${ }^{34}$

33 Sмітн, Desiring (see above, n. 32), 26.

34 Smith makes no distinction between love and desire. See ibid., 51n20. 


\section{Features of a liturgical anthropology}

The key features of Smith's liturgical anthropology are the notions of intentionality and teleology, which are aimed and shaped through embodied formative practices and institutions. ${ }^{35}$ Intending, or intentionality, refers to the way that human persons' "being-in-the-world is always characterized by a dynamic, 'ek-static' orientation that 'intends' the world or 'aims at' the world as an object of consciousness." ${ }^{36}$ The phenomenological tradition, offering an account of the mechanics of how humans are orientated to and relate with the world, has held that, contra Descartes, humans do not simply think but always think of or about something. Human consciousness is intentional, and there are different ways, or modes, of intending. While conscious of a friend, for example, we may be angry at her, remember her, love her, and so on. Among the various options, is there a primary mode? Following Martin Heidegger, Smith takes a critical stance toward the phenomenologist Edmund Husserl and his idea that "perception" was most the fundamental mode of intentionality. Rather than perceiving a world of objects, Smith writes that "we are involved with the world as traditioned actors. The world is an environment in which we swim, not a picture that we look at as distanced observers." ${ }^{37}$ Most pertinent for our purposes here is the claim that the fundamental mode through which humans intend the world is through embodied desires, or loves.

As a mode of intending the world, human desire resides in the body. It engages in intersubjective relations and constitutes human identity in a way which is prior to conscious reflection of who we are and what think we want to do. Though people can reflect on the core of their identity and what they ultimately desire, these may not necessarily align with the desires of the body or be the primary movers and drivers of behavior. According to Smith, humans are constituted by "ultimate loves - that to which we are fundamentally oriented, what ultimately governs our vision of the good life, what shapes and molds our being-in-the-world -in other words, what we desire above all else, the ultimate desire that shapes and positions and makes sense of all our penultimate desires and actions." 38

35 This outline follows Smith's exposition in ibid., 47-63.

36 Ibid., 48.

37 Ibid., 49, emphasis original. Smith finds HeIDEgGER's notion of care in Being and Time (trans. John MACQUARRIE and Edward RoBINSon [New York: Harper \& Row, 1966]) an important shift away from Cartesian perception towards embodiment, though in the end says the mode of desire is most fundamental.

38 Sмгтн, Desiring (see above, n. 32), 49. While there is a similar vocabulary here with Paul Tillich's "ultimate concern," Smith says he is "pluralist about what people and communities worship as ultimate" while Tillich sought "an existential kernel that religions share in common." 
Along with others associated with postmodern philosophy and feminist theory, Smith's deployment of desire seeks to displace the centrality of rationalistic accounts of explaining human behavior. He describes the relationship between desire and behavior this way: "There is a sort of drive (or pull, depending on the metaphor) that pushes (or pulls) us to act in certain ways, develop certain relationships, pursue certain goods, make certain sacrifices, enjoy certain things." ${ }^{39}$ Desire generally operates in ways that cannot be perceived, leading to the possibility that actions and preferences provoked by desire may even be contrary to conscious registers. Donovan Schaefer, a scholar who has explored how affect theory could aid the study of religion, suggests that one way of describing desire is as a sort of compulsion which "at the level of prelinguistic intensity" can "pull bodies independently of linguistic index." For example, while an individual may consciously experience something as sad, "that response in the register of awareness does not dictate our preference-whether our bodies move toward or away from that object" (emphasis added)..$^{40} \mathrm{~A}$ liturgical anthropology thus understands desire as the mode through which humans are pre-cognitively pushed/pulled in certain directions, toward or away from a particular end or telos.

With regard to locating religion, a liturgical lens does not distinguish among teloi according to their ontological status. These ends could be "transcendent" as it is typically defined with some relation to gods or the supernatural. Or the ends could utterly immanent: a certain type of society, a certain lifestyle, etc. Whether the end is superempirical, as with a god, or merely nonempirical, as with justice or the nation, the relevant question is instead going to be the end's relationship to human desire. Thus, no telos would be religious or secular in-and-of itself, since it is not the nature of the telos which makes a person's desire for it religious; rather, the religiosity is found in the way a person intends it: whether or not a person desires it ultimately. A liturgical approach to religion, then, is interested in the dialectical relationship between the beliefs (telos), practices (liturgies), and the strength or intensity of the interaction between the two taking place within a subject (desire). It is necessary, then, to explore the nature of the relationship between desire and the liturgies which form them.

39 Ibid., 51-52.

40 Both quotations are from SCHAEFER (see above, n. 27), 26. 


\section{Liturgical Formation and Institutions}

If humans are able to desire different ends, an account of how desire is oriented in certain directions is needed. While the importance of beliefs and arguments as factors in this process of orientation cannot be denied, they must be seen as one feature of a larger set of forces shaping desire and the bodies that carry it. According to Smith, the hinge on which our desire turns and is aimed is habits, the "precognitive tendencies to act in certain ways and toward certain ends." ${ }^{\prime 1}$ More important than the relatively uncontroversial fact that humans have dispositions to behave certain ways is how these tendencies come to be. This is the process of liturgical formation. First, a telos becomes inscribed by "being pictured in concrete, alluring ways that attract us at the noncognitive level." ${ }^{42}$ These pictures come through the aesthetic means images found, among others, in narratives (e.g. historical and national), in art, in marketing and entertainment. Smith sees these pictures working affectively through the senses, such that they "seep into us" in a way facts and propositions do not. ${ }^{43}$ Repeated, embodied material practices further engage our bodies in deepening the channels through which our desire flows to those ends. While a cognitivist anthropology would emphasize that people are intellectually drawn to one (world)view or another based on their propositions, the desiring model emphasizes that humans' imaginations are captured by images absorbed by affective means. And embodied practices are able to "infuse noncognitive dispositions and skills in us through ritual and repetition precisely because our hearts (site of habits) are so closely tethered to our bodies." ${ }^{44}$ Imagination and the body go hand in hand.

For the purposes of conceptualizing religion in public space, it is important to explore the relationship between the formative practices of an individual and broader society and their institutional forms. Embodied practices which are repeated enough and sufficiently strong to form habits and aim desire cross the boundaries of public and private as constructed in secular liberalism. Like language itself, the liturgical practices that shape desire are constructed intersubjectively, and thus construct, and in turn are constructed by, institutions. As Smith writes:

41 Sмітн, Desiring (see above, n. 32), 55. In Imagining the Kingdom, Smith is more explicit in his debt to Pierre Bordieu's concept of habitus as a "system of structured, structuring dispositions" to “construct (constitute) our world in certain ways." See Sмітн, Imagining (see above, n. 32), 81.

42 Sмгтн, Desiring (see above, n. 32), 58.

43 Ibid. Note that Imagining the Kingdom is a book-length treatment of how the "imagination" element of formation works.

44 Ibid. 
There are no "private" practices; rather, practices are social products that come to have an institutional expression. Practices don't float in society; rather they find expression and articulation in concrete sites and institutions-which is also how and why they actually shape embodied persons. There are no practices without institutions..$^{45}$

Because embodied practices are always aiming our desire toward some end, institutions are thus always teleological. Some vision of the good life, though it may only be implicit, is "carried" in the practices themselves. ${ }^{46}$ This means that formative human practices, being (publically) institutional and teleological, are never neutral with regard philosophical anthropology. Public space is thus always engaging the "visceral register" of human subjectivity. ${ }^{47}$ To the extent, then, that religion is viewed through the lens of liturgy, formative practices and institutions are to be analyzed for how and to what extent they shape human desire and the ends to which they are aimed, and thus for their religious aspects. While the religious neutrality of secular institutions and worldviews has been questioned by a wide range of philosophers and theologians in the last century, ${ }^{48}$ the liturgical lens shifts the focus from epistemological and genealogical issues toward embodied desire.

Locating religion liturgically significantly complicates the typical religious/ secular distinction as understood by scholars of religion, including those who would employ Schilbrack's superempirical/nonempirical distinction. Cultural spheres and institutions normally considered secular and public (the state, schools, the military, universities, and others) would be analyzed not for their reference to the supernatural but instead for their liturgical qualities. Though the teloi of these institutions may not always be articulated, a liturgical anthropology requires scholars to "read" the texts of the practices and the cultural narratives in which they are embedded (and any actual texts, of course) to interpret the kinds of ends to which they point and the way they interact with embodied desire. In

45 Ibid., 62.

46 For further description of how practices carry implicit understanding, see Charles TAYLOR, $A$ Secular Age (Cambridge: Harvard University Press, 2007), 173.

47 William E. Connolly, Why I Am Not a Secularist (Minneapolis: University of Minnesota Press, 1999), $25-27$.

48 Among the more influential recent texts, see John Milbank, Theology and Social Theory: Beyond Secular Reason (Oxford: Blackwell, 1994); for analysis rooted in the Dutch Reformed tradition, see Roy A. Clouser, The Myth of Religious Neutrality: An Essay on the Hidden Role of Religious Belief in Theories (Notre Dame: University of Notre Dame Press, 1991), and Herman DooyeweERd, In the Twilight of Western Thought: Studies in the Pretended Autonomy of Philosophical Thought (Lewiston: Edwin Mellen Press, 1999); for genealogical accounts, see AsAD (see above, n. 8), and Janet R. JAкobsen and Ann Pellegrini, Secularisms (Durham: Duke University Press, 2008). 
interpreting a set of liturgical practices, a scholar could then ask: In what directions are the affective flows in humans being channeled? How can we articulate what may be only implicitly present in these institutions?

\section{Religion as a liturgical continuum}

If all practices and institutions assume a particular telos and form human desire towards that end, the question arises: Are all practices and institutions therefore religious? And does the liturgical lens then fall victim to the same analytical weaknesses of functionalist approaches by categorizing everything as religion? For the liturgical lens to really have any analytic bite, it will indeed need to find some kind of distinction. But rather than the binary religious/secular distinction common in substantivist views of religion, I want to suggest that religion is better conceptualized as a continuum. My contention is that this will allow scholars to better cope with the complexity and ambiguity of the spaces and practices experienced in modern, pluralistic societies where multiple and competing visionssome deemed secular, some religious-operate.

Measuring religiosity and secularity on a continuum or scale is not new. ${ }^{49} \mathrm{But}$ previous measurements have typically relied on belief-centric views of religiosity or categorized behavior based on these assumptions. Instead, I suggest that we think of religiosity on a specifically liturgical continuum. As a heuristic device, the continuum is useful for looking at religion because it opens up space for nuance in descriptions of human behavior and institutions. Rather than the binary of religious/secular based on ontological distinctions, a continuum allows the possibility of describing embodied social phenomena as more or less religious based on liturgical intensity. The primary criterion for where human behavior gets placed on the continuum is the degree to which an embodied activity engages and forms desire. Following Smith, I will describe this criterion as an activity's "thickness." 50 The thinnest behavior is the repeated, embodied activity which seeks some kind of good which is external to the practice, and thus has little to no effect

49 Phil Zuckerman, Luke W. Galen and Frank L. Pasquale, The Nonreligious: Understanding Secular People and Societies (New York: Oxford University Press, 2016), 26.; Benjamin Beit-Hallahmi, "Atheists: A Psychological Profile," in The Cambridge Companion to Atheism, ed. Michael Martin (Cambridge: Cambridge University Press, 2007), 301.

50 Smith himself construes this not as a continuum but as a taxonomic rank in which "ritual" is widest category which includes the smaller category of "practices," while all practices include a smaller category of "liturgies." 
on ultimate desire. ${ }^{51}$ As practices become thicker through more intense aesthetic engagement and shaping of bodily desire, more discernible (though still perhaps implicit) ends are sought. One can think of various kinds of occupations and hobbies which engage the body and senses in this way, like carpentry or hiking. The thickest practices on the continuum are those with the strongest liturgical and there fore religious significance.

Our thickest practices-which are not necessarily linked to institutional religion-have a liturgical function insofar as they are a certain species of ritual practice that aim to do nothing less than shape our identity by shaping our desire for what we envision as the kingdomthe ideal of human flourishing. Liturgies... want to determine what we love ultimately... what we love "above all," that to which we pledge allegiance, that to which we are devoted in a way that overrules other concerns and interests. ${ }^{52}$

There is no doubt that much of what gets called religion in much of contemporary discourse would be considered religious when examined through a liturgical lens. The practices of Islam, Buddhism, or other so-called world religions are aesthetically robust through narrative structures and bodily engagement which channel the flow of human desire toward specific ends, often very explicitly. Yet so do many practices and institutions we call secular. As mentioned above, the rallies, chants, and stories of nationalism are deeply embodied liturgies which have clear substantive ends to which they point. Such a set of practices and ideology engages embodied desire and influences social behavior in ways comparable, if not surpassing, much of what may be considered religion in the modern West.

To assess a practice's thickness, it is not enough to simply observe how much bodily engagement it requires. A seemingly mundane, thin activity like washing hands can be thicker and more deeply engage desire when embedded in a parti-

51 Cf. Alasdair C. MacIntyre, After Virtue: A Study in Moral Theory, 2nd ed. (Notre Dame: University of Notre Dame Press, 2007), 187.

52 Ibid, 86. Cf. Christian Sмгтн's description of liturgy definition: "Liturgy ritually reenacts a tradition, an experience, a history, a worldview. It expresses in dramatic and corporeal form a sacred belief system in words, music, imagery, aromas, tastes, and bodily movement... This is what religious liturgies do. It is also exactly what human social life more generally does with cultural moral order. All of the social practices, relations, and institutions that comprise human social life generally themselves together dramatize, ritualize, proclaim, and reaffirm the moral order that constitutes social life. Moral order embodies the sacred story of the society, however profane it appears, and the social actors are believers in social congregation. Together they remember, recite, represent, and reaffirm the normative structure of their moral order. All of the routines, habits, and conventions of micro interaction ritualize what they know about the good, the right, the true, the just" (emphasis mine). See Moral, Believing Animals: Human Personhood and Culture (New York: Oxford University Press, 2003), 16. 
cular narrative about ritual cleanliness, for example. In this case, the religiosity of handwashing would align with colloquial usage. But the liturgical lens would also suggest that some practices seen as common in secular culture are, when assessed as a set of liturgical practices, sufficiently thick to move them closer to the religious end of the spectrum. For example, one's eating habits, while often thin and mundane, may increase in thickness when connected with other practices, such as certain exercises, and when meals are photographed and shared with a community, tying the meals themselves to a picture of the good life the person desires. While these would fulfill the requirement from Schilbrack that religion needs both functional aspects (practice) and substantive aspects (beliefs), on his definition this example would not qualify as religious because the end of a healthy lifestyle in harmony with other animals and the environment is supposedly contingent on human society. The liturgical lens would instead look at someone's conscious vegetarian shopping, eating, yogic exercises, and the communal sharing of such practices and assess whether this person's diet is playing a liturgical role in shaping their ultimate desires.

\section{Secular, religious, and contested public space}

My claim is that "religion" is more useful as a concept when it is understood as a liturgical continuum rather than as belief in substantive content with a particular ontological status. Having discussed the problems of more traditional ways of locating religion and outlined what a liturgical continuum would look like, I will now discuss some of the specific ways in which this approach is particularly useful when theorizing about how religion relates to politics and public space.

An important advantage of using this liturgical continuum is that it would allow scholars to move beyond the religious/secular binary without having to give up the categories themselves. "Secular" as a category of "nonreligious" would not be abandoned, but it would instead refer to the thin behavior and beliefs with no or minimal teleology. Much of the colloquial use of the terms would be retained. Scholars would still accurately describe a Catholic mass as religious and (most) running clubs as secular. But some putatively secular liturgies-such as a nationalism with weekly rallies and chants-would be considered more religious than a group claiming belief in a deity with virtually no attendant practices. And many such public practices and institutions would be revealed to be no less religious than many consciously religious communities whose presence in public space is a point of contention in secular political environments.

For sociologists, political scientists, anthropologists, and other scholars investigating religion in modernizing societies, a concept which enables the study 
of secularization remains important. Regardless of one's opinion about the sociological predictions and ideological concerns of the secularization thesis, scholars do indeed need tools for assessing what are widely regarded as empirical differences between secular "WEIRD" societies and traditional religious societies. ${ }^{53}$ How would a liturgical view of religion contribute to discussions in this field? A liturgical approach to studying secularization would continue to investigate the observable changes taking place in Western societies, but the categories of such investigations would not be based on the nature of the realities of substantive beliefs. Scholars could still observe and analyze the declines in church and mosque attendance, the changing practices and narratives of these communities, and offer explanations for the causes of these phenomena while projecting their future effects. Secularization would not, however, be necessarily understood as a loss of liturgical formation or "religion" as I am suggesting it be understood. In some cases, the ultimately desired ends may simply have "migrated" towards certain nonempirical contingencies, such as the state. ${ }^{54}$ In theory, a society could decrease the overall intensity of liturgical practices, thinning out its practices and thus moving toward the "secular" end of the continuum. Individuals and groups within a society could clearly do the same. But while certain liturgies may come and go, and some may potentially me less visible and measurable, there would nonetheless be liturgies and institutions forming people's desires and their views of human flourishing.

A liturgical approach will also benefit the study of religion in the public spaces of diverse and complex societies. In pluralistic societies, human desire is subjected to the formative power of multiple competing liturgies which are pushing and pulling people towards different ends. ${ }^{55}$ Most visibly, there is often the liturgy of a self-consciously religious community and its practices embedded in the liturgies of the secular nation-state. But it is also at work as people move between educational formation, political activism, work habits, media consumption, social life and "religious" activity, each exerting liturgical force. These liturgies may have a certain teleological unity, or they may not. But importantly, the liturgical lens would suggest that an analysis of the continuity of liturgies cannot

53 WEIRD stands for Western, Educated, Industrialized, Rich and Democratic. See Joseph HenRich, Steven J. Heine and Ara Norenzayan, “The Weirdest People in the World?" Behavioral and Brain Sciences 33 (2010), 61-83.

54 Such is the thesis of William T. Cavanaugh, Migrations of the Holy: God, State, and the Political Meaning of the Church (Grand Rapids: William B. Eerdmans, 2011).

55 See Sмгтн, Desiring (see above, n. 32), 55n30. See also Kristen Deede Johnson, Theology, Political Theory, and Pluralism: Beyond Tolerance and Difference (Cambridge: Cambridge University Press, 2007), 96-97; Chantal Mouffe, The Return of the Political (London: Verso, 1993), 20-21. 
be limited to the explicit, linguistic level but reach down to embodied practices. What are the social and political effects of being regularly formed by a range of incompatible liturgies? It may be that because the formation of desire is not happening at the conscious level, scholars have not been equipped with the tools for holistically analyzing the effects of religious, social, ethnic, and other parts of diversity. A liturgical lens opens up a new path for exploring when, how, and under what conditions pluralism can cause social cohesion to deteriorate.

Conceptualizing religion liturgically would undoubtedly challenge some of the contours of what has been called "normative" secularism. ${ }^{56}$ To the extent that secularism seeks to limit the public presence of religion, whether in political discourse or more broadly, a liturgical analysis suggests that such efforts are, at best, conceptually inconsistent. Since embodied practices and desire-shaping institutions will be present in some form in all societies, a secularism which conceives of religion as beliefs and practices related to the supernatural is revealed to be a project to restrict only certain forms of religion. Here I would like to circle back to Schilbrack who-despite his differing definition-gives an apt description of how a liturgically-informed view of religion would understand the political and contested nature of public space:

Religion may not be a structure as much as a space of contestation between different constituencies who use the stories, rituals, and institutions that mark off that space as tools to establish their own norms as the authoritative ones. In fact, those who continue to use the label 'religion' should clarify that something may be a religion without a name, and therefore may not exist in the minds of its practitioners as an entity separate from the rest of the culture. $^{57}$

The only modification I would make is that this is true of religious and secular spaces. Religion and politics are both operating in that space of contestation in which people's desires are formed by liturgies, in which different norms aimed at distinct views of human flourishing come into contact, all seeking-consciously or not-to establish their own normative claims. Labeling certain constituencies with equally formative liturgies as religious and others as secular masks the contestable nature of that space and serves to privilege certain modes of discourse and practices over others. A liturgical lens contests the obfuscating labels and the operational notions of religion to level the playing field of that space and enable a more deeply pluralistic and egalitarian engagement between these constituencies.

56 Saba Mанмоор, “Secularism, Hermeneutics, and Empire: The Politics of Islamic Reformation,” Public Culture 18 (Apr 1, 2006), 323-347.

57 Schilbrack (see above, n. 17), 86. 


\section{Conclusion}

In this article, I have questioned the usefulness of common conceptualizations of religion for theorizing about its place in public space and instead suggested the use of a liturgical continuum. Debates about the proper relationship between religion and politics have been hindered by definitions of religion which are not suited to the purpose of grappling with the complexity and contested nature of the space in which religion and politics operate. After reviewing some of the main critiques of substantivist and functionalist approaches to religion and suggesting that "religion" cannot be abandoned as a concept, I interrogated the hybrid proposal of Kevin Schilbrack and found his religious/secular distinction relying on an overly cognitivist anthropology.

To propose an analytically useful approach to the study of religion in public life, I drew on the work of James K. A. Smith and suggested that a liturgical lens offers considerable insights. By moving away from seeing religion as beliefs in certain types of realities, the liturgical model refocuses scholarly attention on social practices and institutions and the intensity with which they shape embodied desire. My suggestion is that religion is then better understood as a continuum measuring the thickness of beliefs and behavior, i.e. how much they engage and shape bodily desire. Crucially, this allows scholars to maintain the category of "secular" and not deem all things or societies equally religious, while also challenging the obfuscating religious/secular labels that are assigned to individuals and groups based on extremely thin beliefs and ignore robust liturgical practices. The liturgical continuum suggests that public spaces and the institutional practices of which they are made will always shape human desire, and thus always have some level of religiosity. By unmasking the lack of neutrality of public space and seeing it inherently as a place of contestation of various liturgies, theorists are thus better equipped to explore a more genuine pluralism in which religious and secular constituencies have equal access. 
